\title{
ANTECEDENTS OF TURNOVER INTENTIONS: A STUDY OF KARACHI BUSINESS SCHOOLS
}

\author{
Muhammad Ashraf 1 \\ Research Scholar, Indus University, Karachi, Pakistan \\ Nawaz Ahmad2 \\ Assistant Professor, IoBM \\ Sheema Haider3 \\ Director \\ Quality Enhancement Cell (QEC) \\ Indus University, Karachi, Pakistan
}

\begin{abstract}
Purpose: This study mainly investigates the factors, like job satisfaction, affective commitment, perceived organizational support and distributive justice as antecedents of turnover intentions.

Methodolgy: This study utilized the quantitative approach by distributing questionnaires to 200 employees working in leading business schools of Karachi, Pakistan. The correlation and regression analyses have been performed. Findings: The results of the study revealed that, all the predictors negatively correlated and influenced turnover intention.

Practical Implitation: The findings and framework of this study will be useful to the university organizations, in identifying the factors making the employees working with them to quit. Pakistan is believed to be the potential Market for Investment in Education. This empirical attempt can be used as kick start for investment in this sector. By taking corrective measures the university organizations can retain knowledge workers, and avoid the anguishes of new hiring.
\end{abstract}

Keywords: Turnover intention, affective commitment, distributive justice, Job Satisfaction, POS, Business Schools, Karachi, Pakistan

\footnotetext{
* The material presented by the author does not necessarily portray the viewpoint of the editors and the management of the Institute of Business \& Technology (IBT)

1 Muhammad Ashraf

:professycom@yahoo.com

2 Nawaz Ahmad

:nawazahmad_pk@hotmail.com

3 Sheema Haider

:qec@indus.edu.pk

(C) IBT-JBS is published by the Institute of Business and Technology (IBT).

Main Ibrahim Hydri Road, Korangi Creek, Karachi-75190, Pakistan.
} 


\section{INTRODUCTION}

Selection and recruitment are happening to be core components of the central activities of human capital management: such as hiring, career growth, and monetary benefits for the employees. The identified activities constitute an undeviating part and parcel of the HR managers. The process of selection and recruitment is equally significant both for budding and groomed businesses. With regard to the human resources management the recruitment is a procedure of finding, and inducting the desired candidate to a firm .The HR Department of any organization use to operate with support of expertise of sourcing, who keep helping the HR Managers in wisdom based hiring decisions. These hiring experts invovled in numerous steps like sourcing candidate, tracking and reviewing candidacy, short listing of applicants, organizing and executing interviews for employement. Inducting efficient workers is a facinating step of going away in the selection process, however establishing and retaining a loyal workforce is required to be more facilitated by the induction of sophisticated HRM infrastructure ; . Logically, the policies and practices regarding HRM can be strategically formulated and implemented to improve desired employee productivity, just like enhancement in employee dedication, commitment, and the role delegated to him/her for employee role enrichment. Despite of such vigorous investments, organizations are still on their toes to develop tricks and tips, so that corporate and employee relationship may be strengthened. However, feeble worker-corporation relationships are often exhibited in terms of high employee turnover. Normally, people are looking for the job offering better salary, monetary rewards and career growth chances. The conventional techniques that lay heavy emphasis on competitive salaries normally carry meager success in employee retention and job inspiration. Such restrain has made the practitioners to revolve their intelligence around the services of sophisticated Human Resources Management infrastructures, numerous steps to improve employee loyalty for their company, for instance organization culture, selection methods, incentives in lieu of employee value addition, and gloomy perks to all workers. Like all organization the educational institutions are breathing under the issue of retaining talent. Problems of employee retention becomes epidemic for higher educational institutions of Pakistan . The majority of higher educational institutes of Pakistan are specifically facing problem of turnover, because there is tremendous amount of pressure on degree awarding institutes to produce graduates, so that dire needs of dynamic corporate sector can be satisfied . Pakistan is a country where investing in education sector has been considered as vibrant. The importance of academic institutions in providing skilled manpower needed for communal, economic and scientific development cannot be denied. The nations having organized educational institutions are considered to be an inventory of trained and skilled cerebrals. Such institutions are serving as stockroom of intellect, wisdom and knowledge for development of skilled manpower. Hence realizing the significance of knowledge providing institutions, the importance of knowledge imparting academic staff and supporting staff emerges .The academic institutions without dedicated and well qualified cannot achieve the milestone. Higher educational institutions have heavily reliance on knowledge staff more than any other organizations. This has necessitated the institutions to formulate the strategies to retain their intellectual staff. 


\subsection{Problem statement}

Corporate world has been continuously struggling with employee retention. The monetary implications of employee turnover, re-hiring, training, placement are soaring, particularly higher educational institutions. Pakistani Universities are no exceptional. A few empirical evidences are available regarding the factors predicting turnover intentions among university employees both academic and administrative. General perception prevails among the researchers that there is negative association between job contentment and intent to leave. In order to prove the perception this study intends to carryout exploratory investigation, and the extent of predicting turnover intentions through affective commitment, supervisor support, job satisfaction and distributive justice.

\subsection{Objectives of the study}

This study fouces on:

$\varnothing \quad$ To investigate factors predicting turnover intent among employees of Business Schools of Karachi, Pakistan.

$\varnothing \quad$ To Emprically test the extent to which level of job satisfaction among employees of Business Schools of Karachi, Pakistan predict the turnover intent.

$\varnothing \quad$ To study whether Affective commitment do influence the level turnover intention among employees of Business Schools of Karachi, Pakistan.

$\varnothing \quad$ To explore the influence of organizational support in predicting turnover intent among employees of Business Schools of Karachi.

$\varnothing \quad$ To evaluate extent of distributive justice perception in predicting turnover intent among employees of Business Schools of Karachi, Pakistan.

\subsection{Significance of Research}

The findings of this study will contribute in turnover intention literature, in terms of academic and administrative staff of business schools. Emprical results of this study can provide eyes and ears regarding the role of identified factors in predicting turnover intentions. Moreover the outcome of this study can be used by the business schools of Pakistan struggling with talent retention.

\section{ACADEMIC CONTEXT}

\subsection{Turnover Intention}

Turnover intention hardly ever concisely described term in studies . Bester further describes, this is so because, this practice is possibly associate-able to the idea that people feel it to be self-explanatory (Bester). Various scholars (Steers, 1977; Mowday, Steers, \& Porter, 1979; Mobley, 1982; Hom, Griffeth, \& Sellaro, 1984; 
Muliawan, Green, \& Robb, 2009) considered turnover intention as last step in executing decision process before an individual essentially quit workplace. Thus turnover intention can be explained as a person's collective reaction to the inner or outer stimuli. Ajzen and Fishbein's (1975) outline of premediated behavior, to quit the work of the firm. According to Lacity, Iyer and Rudramuni (2008) turover intention can be defined as "the extent to which employee plans to leave the organiztion" (p.228). To accomplish the objective of this study the definition "the concious and deliberate wilfulness to leave the organization" (Tett \& Meyer, 1993, p.262), has been used.

Turnover is an outcome of countering strategy used by workers to get flee from existing mindbogling situation (Petriglieri, 2011). Turnover can be eternal, when workers quit the employement organization, or it can be identified as horizontal movement when workers tries and intend transfer to new department. In other words turnover intention is "the last in a sequence of withdrawal" (Tett \& Meyer, 1993, p.262). An execise that is carried out in the words of Petriglieri (2011, p. 648) is "identity exit".

\subsection{Consequences of Turnover Intention}

Quiting or switching a job may not be the frequent decission of an employee, however the decission to exit is caused by numerous individualistic and contextual factors such as employement opportunities and employee market scenario. An enployee's turnover intention is relied on perceived opportunities and effortless hunting of another job (Particualrly in stressed market situation), the role of mobility intelligence, and personal characteristics in exploring behvaiour. Substitute job opportunities thus persuade real employee turvover behaviour (Bellou, 2008; Agarwal, Ferratt, \& De, 2007;Carmeli \& Gefen, 2005;Akgünb \& Lynn, 2002;Boies \& Rothstein, 2002; Brown, 1996;Allen \& Meyer, 1996). In the words of Bothma (2012) the turnover situation has noteworthy monetory and allied negative outcomes for any firm. The loss of skilled employees turns disastereous consequences to organizations, like hampered organizational operations, execution of serivices and management. It may bring more devastating results in terms of cost for hiring and training the new employees, and also time to equate with organizational culture ; . The disucssed implications have made sound reasoning for the validation of the study.

\subsection{Job Satisfaction and Turnover Intention}

The most important component in an organizational gain is the level of satisfaction of employees. Job satisfaction has been explained in several contexts by number of scholars .The level of job satisfaction among employees use to predict numerous behaviours of employees while in working environment. For example Saifuddin, Hongkrailert, and Sermsri (2008) have concluded that low absenteeism is linked with elevated level of satisfaction with job, and vise versa. Karsh, Booske, and Sainfoert (2005) found that satisfaction with job and organizational commitment are significant determinants of turnover intentions. However job satisfaction is not sole sufficient enough to determine the turnover intentions, organizational commitment is also be required to be considered turnover model as manipulated variable. Researchers have 
registered number of findings with academic research regarding job satisfaction and turnover intention. Serveral studies of them in various organizational settings concluded significant negative correlation between job satisfaction and turnover intentions. A correlational study making IT professionals as investigative subjects, found negative correlation between turnover intention and job satisfaction.

H1a: The level of job satisfaction and turnover intention are negatively correlated.

H1b: Job satisfaction will inversely influence Turnover Intention among employees of business schools of Karachi.

\subsection{Role of Affective Commitment in Predicting Turnover Intent}

Tremendous amount of empirical studies has associated affective commitment with turnover intentions of people in working environment, and also cuase of high turnover. The research scholars like Allan and Meyer (1991) innovated three sorts of commitments: normative, continuance and affective. The touchy affliation, emotional associatin with organization is termed as Affective commitment. When an employee is in a state of affection with organiztion, to him/her leaving the organization is like a question of survival. Thus affective commitment influences turnover intention negatively . Infact affective commitement have positive impact on recognition of change. The findings of several studies confirms that workers with healthy affective commitment contribute with dedication and efficiently compare to their counterpart having feeble affective commitment ;;.

H2a: The Affective commitment negatively correled with turnover intention.

H2b: The affective commitment will inversely influence Turnover Intention among the employees of business schools in Karachi.

\subsection{Perceived Organizational Support and Employee Turnover Intent}

The human resources mangement researchers, have started to recognize the benefit of investigating link between conditions that prevails at several levels of the organization . Responding to such trend management scholars have discovered, how behaviors of an employee at one end of the firm effect the behaviors and attitudes of an employee at other end. One aspect of attention is the impact of Supervisory-position attitudes with subordinate-position behaviors and attitudes (e.g.,Tepper \& Taylor, 2003;Shanock $\&$ Eisenberger, 2006). Since supervisors are considered to be intermediaries between organiztions and subordinates, therefore subordinates use to attribute such supportiveness from the part of orgnization rather than only from the side of supervisor's individualistic support . Consequently, perceptions of supervisors' support contains a significant impact on suboridinates' perceived organizational support (POS). Despite of too much significance of subordinates' perceived organizatinal support in turnover intentions, there are very negligible theoritical and emprical evidences regarding the POS and turnover intention among employees of educational institutions. 
H3a: Perceived organizational support (POS) negatively correlated with turnover intention.

H3b: Perceived organizational support will inversely influence Turnover Intention among employees working in business schools of Karachi.

\subsection{Role Of Distributive Justice in Predicting Turnover Intent}

Various past studies concluded that distributive justice influences several variables that have been judged as strong predictors of turnover for example satisfaction with job and commitment. In this regard a study has authenticated the pathway leading from fair distributive perception to increased satisfaction level, and eventually decreasing the intention to switch or leave the organization . The perception of employees regarding organizational practices is very important, and may influence numerous employee behaviours. The perception of fair distribution has been declared as strong negative predictor of turnover intention. Hetidrix et. al. (1991) were of belief that very little emprical studies have been conducted, which could be considered an all-inclusive model of influence of procedural and distributive justice on factors as the significant predictors of turover, contentment and commitment. Scholars have frequently utilized exhange framworks (e.g.,Niehoff \& Moorman, 1993) and sensitivity of contract type to enumerate the link between justice and behaviour toward organization. The customer satisfaction is heavily depend upon the level satisfaction of an employee who is rendering services. Therefore while formulating policies organizations are compelled to incorporate employee attitude related diagnostic mechanism. The nature of service based job requires the employee to give cent percent in terms of attitude towards organizational productivity. Educational institutions are such service based organizations, which impart knowledge services. Thus the perception of employees regarding organizational policies and procedures essentially influeces work related attitudes of employees working in educational institutions, hence we propose the following hypothesis to emprically test:

H4a: The distributive justice is negatively correlated with turnover intention.

H4b: Distributive justice will inversely affect turnover intention of employees of business schools in karachi.

\section{METHODOLOGY}

Based on given above extensive literature review, the theoretical framework of this study can be depicted as under: 


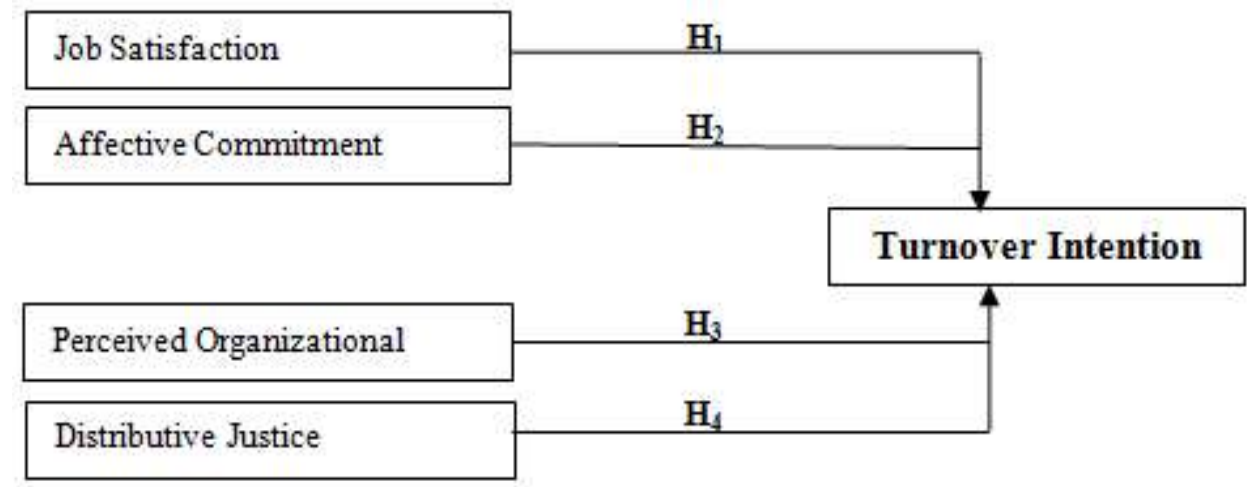

Figure.1: Theoretical framework

\subsection{Data Collection}

The rationale of this study is to determine the factors predicting turnover intention among employees of business schools of Karachi, Pakistan. In this regard four leading business schools based in Karachi, Pakistan have been made population interest. The study is based primary data source.

\subsection{Measurement}

\subsubsection{Measures}

As the purpose of this study is to determine the predictors of turnover intention, and their predicting strength therefore turnover intention is endogenous variable, whereas job satisfaction, affective Commitment, perceived organizational support (POS) and distributive justice are exogenous variables. Several established data collection instruments were used to gather the responses from the selected subjects to substantiate the purpose of the study.

\subsubsection{Dependent Variable}

\subsubsection{Turnover Intention}

Intention to quit the organization was measured with 4-item scale developed by Michaels and Spector (1982) was used. The five point likert scale was used from least to most state of agreement.

\subsubsection{Independent Variables}

\subsubsection{Job Satisfaction}

To measure the level of job satisfaction an established scale developed by Brayfield \& Rothe (1951) was used. The scale was afterward adapted by Moorman (1991). The cronbach's alpha for the scale reported by both authors were 0.87 and 0.86 
respectively. However in our case study the scale reported 0.81 due to some changes in items to serve the purpose of the study. The result is depicted in table No. 3.

\subsubsection{Affective commitment}

The scale of Meyer and Allen (1997) was used for this study in order to measure the level of affective commitment among employees working in selected business schools of Karachi, Pakistan. In order to serve the purpose of the study, some mild changes had been made in the scale.

\subsubsection{Perceived Organizational Support}

The perception of employees regarding organizational support was measured through the scale used in the study conducted by Shanock and Eisenberger (2006).

\subsubsection{Distributive justice}

The perception of business school employees regarding distributive justice prevailed in their respective organization was measured by the scale developed by Niehoff and Moorman (1993).

\subsection{Data analysis}

In order to analyze the collected data, statistical software SPSS 20 was used. Statistical analysis was performed through statistical tools, so that the nature of relationship among variables of interest can be examined. To determine the influence of antecedents of turnover intention among the employees of business schools, the mean and standard deviation of job satisfaction, Affective commitment, Perceived organizational support and distributed was calculated. Besides that correlation analysis was performed with the objective to test the nature of association among variables of interest. The benchmark for measuring correlation between variables of interest is: 1 ? $r$ ? 1.Moreover regression analysis was performed to measure the degree of influence among the variable of this study.

\section{RESULTS}

The characteristics of sample and rate of response has been shown in table 1 . The number of questionnaire was 200 distributed among the selected respondents of selected business schools of Karachi, Pakistan. In return 190 duly filled questionnaires were acquired. Hence the response rate was 95\%. (See Table 1 in Appendix) 


\subsection{Descriptive Statistics}

The demographic peculiarities for this study are shown in table 2. The statistics in the given table shows that 110 out of 190 respondents were male, and rest was female respondents. Thus the greater chunk of respondents was male which constitutes slightly more than 57 percent. The respondents were also requested to opt their age group from the given choices. Thus 123 respondents were of up to 30 years of age, 34 were of up to 40 years of age, and rest of the respondents were more than 41 years old. Result shows than 64.73 percent of total respondents were of up to 30 years of age which more than any other given option for age group. The business schools of Karachi are populated with young employees. The table also shows the nature of job of the employees. The respondents were categorized into academic and administrative nature of job, 113 out of 190 respondents were associated to administrative nature of job, which is near to 60 percent of total respondents.(See Table 2 in Appendix)

\subsection{Reliability Analysis}

The Cronbach's Alpha reliability test used to report internal consistency among the items of the scale. The coefficient of the said test normally lies between 0 and 1 . As a rule of thumb, for conducting cronbach's alpha reliability test following standards are normally adopted " $>.9=$ Excellent, $>.8=$ Good, $>.6=$ Questionable, $>.5=$ Poor and $<.5=$ Unacceptable". The values of this test for this study were between 0.77 to 0.81 which evidenced good internal consistency for each construct. The results of the said test is shown in table 3 (See Table 3 in Appendix)

\subsection{Correlation Analysis}

The mean score for turnover intention was $3.2(\mathrm{SD}=0.86)$, Job satisfaction 3.2 ( $\mathrm{SD}=0.84)$, Affective Commitment $2.4(\mathrm{SD}=0.79)$, Perceived organizational support $4.4(0.70)$, and distributive justice $3.3(0.56)$ are reflected in Table 4. Correlation analysis results revealed, that turnover intention was negatively correlated with all factors of interest in this study i.e. Job satisfaction and turnover intention $(\mathrm{r}=-0.564$, $\mathrm{p}<0.01$ ), Affective Commitment and turnover intention ( $\mathrm{r}=-0.357, \mathrm{p}<0.01)$, Perceived organizational support and turnover intention $(\mathrm{r}=-0.011, \mathrm{p}<0.01)$, and distributive justice and turnover intention was $(\mathrm{r}=-0.357, \mathrm{p}<0.01)$. Results revealed that job satisfaction was inversely related to turnover intention $(\mathrm{r}=-0.45, \mathrm{p}<0.01)$. Whereas affective commitment highly correlated with job satisfaction $(\mathrm{r}=0.706, \mathrm{P}<0.01)$, perceived organizational commitment and distributive justice revealed weaker positive correlation with job satisfaction $(\mathrm{r}=0.207, \mathrm{P}<0.01),(\mathrm{r}=0.378, \mathrm{P}<0.0 .1)$ respectively. Perceived organizational support and distributive justice showed similar strength of correlation with affective commitment $(\mathrm{r}=0.571, \mathrm{P}<0.01)$. The distributive justice showed moderate correlation with perceived organizational support $(r=0.446, \mathrm{P}<0.01)$ (Table 4). The correlation analyses results supported $\mathrm{H} 1 \mathrm{a}, \mathrm{H} 2 \mathrm{a}, \mathrm{H} 3 \mathrm{a}$ and $\mathrm{H} 4 \mathrm{a}$ of this study. (See Table 4 in Appendix) 


\subsection{Regression Analysis}

Table 5 given below shows the outcome of regression analysis. Multiple linear regression models were developed by making job satisfaction, affective commitment, perceived organizational support and distributive as predictors of turnover intentions. The results given in the table shows that whether the level of job satisfaction among employees predicts the turnover intentions $(\hat{a}=-.593, \mathrm{p} .<.01)$. Hence higher the level of job satisfaction, lower the turnover intention. Similarly there is inverse relation between affective commitment and turnover intention ( $\hat{\mathrm{a}}=-.357, \mathrm{p} .<.01)$. Another factor Perceived organizational support shows inverse significant influence on turnover intention $(\hat{\mathrm{a}}=-.307, \mathrm{p} .<.01)$. Thus, the employees of business schools in Karachi, perceives that if there is enough organizational support with employees the intentions to quit or switch the job is minimized. The distributive justice ( $\hat{\mathrm{a}}=-.302, \mathrm{p} .<.01)$. The fair perception about the distribution of monetary and non-monetary benefits among employees urges the employees to stick with organization. The regression analyses of this study support the proposed hypotheses $\mathrm{H} 1 \mathrm{~b}, \mathrm{H} 2 \mathrm{~b}, \mathrm{H} 3 \mathrm{~b}$ and $\mathrm{H} 4 \mathrm{~b}$.(See Table 5 in Appendix)

\section{DISCUSSION}

The finding that job satisfaction is inversely related to turnover intention is in alignment with the study concluded by Valentine et. al. (2010). Conceptually it makes sense a more satisfied employee will stick with organization for long time. Affective commitment in this study refers to the level of employee emotional attachement with the organization. In this regard the results of this study found inverse relation of affective commitment with turnover intention, so as concluded by Wasti (2003). The results of this study regarding inverse influece of perceived organizational support on turnover intention supports the finidings of Hussain and Asif (2012). Employees having high level of organizational support, are less prone to haunt by turnover intention. The fair perception of employees regarding distribution of financial and non financial benefits on equaity basis, will make the employee to stick with organization .

\section{REFERENCES}

Agarwal, R., Ferratt, T. W., \& De, P. (2007). An experimental investigation of turnover intentions among new entrants in it. The Data Base for Advances in Information, 38(1),8-28. doi:10.1145/1216218.1216222.

Ajzen, I., \& Fishbein, M. (1975). Attitude-Behavior Relations: A Theoretical Analysis and Review of Empirical Research. Psychological Bulletin, 84(5),8-918.

Akgünb, A. E., \& Lynn, G. S. (2002). Antecedents and consequences of team stability on new product development performance. Journal of Engineering and 
Technology Management, 19(3-4),263-286. doi:10.1016/S0923-4748(02)00021-8.

Allen, N. J., \& Meyer, J. P. (1996). Affective, Continuance, and Normative Commitment to the Organization: An Examination of Construct Validity. Journal of Vocational Behavior, 49(3),252-276. doi:10.1006/jvbe.1996.0043.

Bartlett, I. ,., Kotrlik, J. W., \& Higgins, C. C. (2001 ). Organizational Research: Determining Appropriate Sample Size in Survey Research. Information Technology, Learning, and Performance Journal, Vol. 19, No. 1, , 19(1), 43-50.

Beechler, S. L., Bird, A., \& Raghuram, S. (1993). Linking Business Strategy and Human Resource Management Practices in Multinational Corporations: A Theoretical Framework.

In B. Prasad (Ed.), Advances in International Comparative Management: A Research Annual (pp. 199-215). Greenwich, CT: JAI Press.

Bellou, V. (2008). Exploring civic virtue and turnover intention during organizational changes. Journal of Business Research, 61(7),778-789. doi:10.1016/j.jbusres.2007.09.001.

Bester, F. (2012). A model of work identity in multicultural work settings. Johannesburg: Unpublished D.Phil Thesis, University of Johannesburg.

Boies, K., \& Rothstein, M. G. (2002). Managers' interest in international assignments: the role of work and career satisfaction. International Journal of Intercultural Relations, 26(3),233-253. doi:10.1016/S0147-1767(02)00002-0.

Borman, W. C. (1993). Expanding the criterion domain to include elements of contextual performance. In \&. W. In N. Schmitt, Personnel Selection in Organization (pp. 71-98). New York: Jossey-Bass.

Bothma, C. F. (2012). The consequences of employees' work-based identity. Johannesburg: Unpublished DCom thesis, University of Johannesburg. Retrieved from http://hdl.handle.net/10210/4999.

Brayfield, A. H., \& Rothe, H. F. (1951). An index of job satisfaction. Journal of Applied Psychology, 35(5),307-311. doi:10.1037/h0055617.

Brown, S. P. (1996). A meta-analysis and review of organizational research on job involvement. Psychological Bulletin, 120(2),235-255. doi:10.1037/00332909.120.2.235.

Cammann, C., Fichman, M. D., Jenkins, \& Klesh, J. (1979). The Michigan Organizational 
Assessment Questionnaire. Michigan: University of Michigan Ann Arbor.

Carmeli, A., \& Gefen, D. (2005). The relationship between work commitment models and employee withdrawal intentions. Journal of Managerial Psychology, 20(2),63-86. doi:10.1108/02683940510579731

Coole, D. R. (2003). The effects of citizenship performance, task performance, and rating format on performance judgments. Florida: University of South Florida Scholar Commons.

Devonish, D., \& Greenidge, D. (2010). The Effect of Organizational Justice on Contextual Performance, Counterproductive Work Behaviors, and Task Performance: Investigating the moderating role of ability-based emotional intelligence. International Journal of Selection and Assessment, 18(1),75-86. doi:10.1111/j.1468-2389.2010.00490.x

Doç, Y., \& DOGAN, D. H. (2008). A Research Study For Procedural Justice As A Factor in Employee Retention. Journal of Economics and Administrative Sciences, 15(2), 61-71.

Donsbach, J. S., \& Shanock, L. R. (2008). Relationship between Supervisor Turnover intention and Subordinate Perceived Organizational Support and Positive Mood. Psychologica Belgica, 48(2 \& 3), 243-259. doi:http://dx.doi.org/10.5334/pb-48-2-3-243

Ejiro, A. N., \& Mon, N. (2000). Factors Influencing Academic Staff Turnover in Nigerian Universities. Higher Education Review, 36(1),45-56.

Essays, UK. (2013, November 13). Impact Of Organizational Justice On Teachers Outcomes Psychology Essay. Retrieved from http://www.ukessays.com/essays/psychology/impact-of-organizationaljustice-on-teachers-outcomes-psychology-essay.php?cref $=1$ : UKESSAYS.com

Folger, R., \& Konovsky, M. A. (1989). Effects of procedural and distributive justice on reaction to pay raise decsssion. Academy of Managment Journal, 3, 141183.

French, R., \& Rumbles, S. (2013). Recruitment and Selection. In G. Rees, \& R. French, Leading, Managing and Developing People (4 ed., pp. 169-170). London: CIPD Enterprises Limited. Retrieved July 9, 2014, from www.cipd.co.uk

George, D., \& Mallery, P. (2003). SPSS for Windows step by step: A simple guide and reference 11.0 update (4th ed.). Boston: Allyn \& Bacon.

Gliem, J. A., \& Gliem, R. R. (2003). Calculating, Interpreting, and Reporting Cronbach's Alpha Reliability Coefficient for Likert-Type Scales. Midwest Research- 
to-Practice Conference in Adult, Continuing, and community Education (pp. 82-88). Columbus: The Ohio State University Columbus. Retrieved from https://scholarworks.iupui.edu/bitstream/handle/1805/344/Gliem\%20\&\% 20Gliem.pdf?s

Guntur, R. Y., Haerani, S., \& Hasan, M. (2012). The influence of affective, continuance and normative commitments on the turnover intentions of nurses at Makassar's private hospitals in Indonesia. African Journal of Business Management, 6(38),10303-10311. doi:10.5897/AJBM11.1715

Hassan, S. (2010). Fair Treatment, Job Involvement, and Turnover Intention of Professional Employees in Government: The Importance of Organizational Identification as a Mediator. Ohio: (Doctoral Dissertation)John Glenn School of Public Affairs, Department of Public affairs and Policy.

Hetidrix, W. H., Robbins, T., Miller, J., \& Summers, T. P. (1991). Effects of Procedural and Distributive Justice on Factors Predictive of Turnover. Journal of Social Behavior and Personality, 13(4),611-632.

Hom, P. W., Griffeth, R. W., \& Sellaro, C. L. (1984). The validity of mobley's (1977) model of employee turnover. Organizational Behavior and Human Performance, 34(2),141-174. doi:10.1016/0030-5073(84)90001-1

Howard, M. H., \& Homma, M. (2001). Job satisfaction of Japanese career women and its influence on turnover intention. Asian Journal of Social Psychology, 4(1),23-38. doi:10.1111/1467-839X.00073

Hussain, T., \& Asif, S. (2012). Is Employees' Turnover Intention Driven By Organizatiional Commitment and Perceived Organizational Support? Journal of Quality and Technology Management, 8(2),01-10.

Jankingthong, K., \& Rurkkhum, S. (2012). Factors Affecting Job Performance: A literature Review. Silpakorn University Journal of Social Sciences, Humanities, and Arts, 12 (2),115-127.

Johnston, I. G., \& Snizek, W. E. (1991). Combining head and heart in complex organizations: a test of Etzioni's dual compliance structure hypothesis. Human Relations, 44(12),1255-1272. doi:10.1177/001872679104401202

Karsh, B., Booske, B. C., \& Sainfort, F. (2005). Job and organizational determinants of nursing home employee commitment, job satisfaction and intent to turnover.

Ergonomics, 48(10),1260-1281. doi:10.1080/00140130500197195 Kirpal, S. (2004). Work identities of nurses: Between caring and efficiency 
demands. Career Development International, 9(3),274 - 304. doi:10.1108/13620430410535850

Kozlowski, S. W., \& Klein, K. J. (2000). A multilevel approach to theory and research in organizations: Contextual, temporal, and emergent processes. In K. J. Klein, \& S.

W. Kozlowski (Eds.), Multilevel theory, research, and methods in organizations: Foundations, extensions, and new directions (pp. 3-90). San Francisco, CA, US: Jossey-Bass.

Krejcie, R. V., \& Morgan, D. W. (1970). Determining Sample Size for Research Activeties. Educational and Psychological Measurement, (30), 607-610.

Lacity, M. C., Iyer, V. V., \& Rudramuni, P. S. (2008). Turnover intentions of Indian IS professionals. Information Systems Frontiers, 10(2),225-241. doi:http://dx.doi.org/10.1007/s10796-007-9062-

Mayhew, R. (2014, July 5). Appropriate Criteria for an Effective Recruitment \& Selection Program. Houston, Texas, USA.

Mbah, S. E., \& Ikemefuna, C. O. (2012). Job Satisfaction and Employees' Turnover Intentions in total Nigeria plc. in Lagos. International Journal of Humanities and Social Science, 2(14),275-287.

Meyer, J. P., \& Allen, N. J. (1997). Commitment in the Workplace Theory, Research, and Application. Thousand Oaks CA: SAGE Publications, Inc .

Meyer, J. P., \& Allen, N. J. (1997). Commitment in the Workplace Theory, Research and Application. Thousad Oaks CA: SAGE Publications, Inc.

Miceli, M. P., Jung, I., Near, J. P., \& Greenberger, D. B. (1991). Predictors and outcomes of reactions to pay-for-performance plans. Journal of Applied Psychology, 76(4),508-521. doi:10.1037/0021-9010.76.4.508

Mobley, W. H. (1982). Some Unanswered Questions in Turnover and Withdrawal Research. Academy of Managment Review, 7(1),111-116. doi:10.5465/AMR.1982.4285493

Mohamed, S. A. (2014). The Relationship between Organizational Justice and Quality Performance among Healthcare Workers: A Pilot Study. The Scientific World Journal, 2014(2014), 1-7. doi:http://dx.doi.org/10.1155/2014/757425

Moorman, R. H. (1991). Relationship between organizational justice and organizational citizenship behaviors: Do fairness perceptions influence employee citizenship? Journal of Applied Psychology, 76(6),845-855. doi:10.1037/0021- 
Mowday, R. T., Steers, R. M., \& Porter, L. W. (1979). The measurement of organizational commitment. Journal of Vocational Behavior, 14(2),224-247. doi:10.1016/0001-8791(79)90072-1

Mubarak, R. Z., Wahab, Z., \& Khan, N. R. (2012). Faculty retention in higher education institutions of Pakistan. Ricerche di Pedagogia e Didattica - Journal of Theories and Research in Education, 7(2),65-78. doi:10.6092/issn.1970$2221 / 3213$

Muliawan, A. D., Green, P. F., \& Robb, D. A. (2009). The turnover intentions of information systems auditors. International Journal of Accounting Information Systems, 10(3),117-136. doi:10.1016/j.accinf.2009.03.001

Niehoff, B. P., \& Moorman, R. H. (1993). Justice as a Mediator of Relationship Between Methods of Monitoring and Organizational citizenship Behavior. Acadmy of Managment Journals, 36(3), 527-556. doi:10.2307/256591

Niehoff, B. P., \& Moorman, R. H. (1993). Justice as a Mediator of the Relationship between Methods of Monitoring and Organizational Citizenship Behavior. The Academy of Management Journal, 36(3),527-556.

Niehoff, B. P., \& Moorman, R. H. (1993). Justice as a Mediator of the Relationship between Methods of Monitoring and Organizational Citizenship Behavior. The Academy of Management Journal, 36(3),527-556. Retrieved from http://www.jstor.org/stable/256591

Perryer, C., Jordan, C., \& Travaglione, A. (2010). Predicting turnover intentions: The interactive effects of organizational commitment and perceived organizational support.

Management Research Review, 33(9),911-923. doi:10.1108/01409171011070323

Petriglieri, J. L. (2011). Under Threat: Responses to and the Consequences of Threats to Individuals' Identities. Academy of Managment Review, 36(4),641-662. doi:http://dx.doi.org/10.5465/amr.2009.0087

Plamondon, K. E. (2000). Adaptibility in Adaptability in the workplace: development of a taxonomy of adaptive performance. Journal of Applied Psychology, $85(4), 612-624$.

Preston, J. B., \& Brown, W. A. (2004). Commitment and performance of nonprofit board members. Nonprofit Management and Leadership, 15(2),221-238. doi:10.1002/nml.63 
Rahman, A., Naqvi, S. M., \& Ramay, M. I. (2008). Measuring Turnover Intention: A Study of IT Professionals in Pakistan. International Review of Business Research Papers, 4(3),45-55. Retrieved from http://www.bizresearchpapers.com/

Roodt, G. (1997). Theoretical and empirical linkages between workrelated commitment foci. SA Journal of Industrial Psychology, 23(2),6-13. doi:10.4102/sajip.v23i2.624

Saifuddin, Hongkrailert, N., \& Sermsri, S. (2008). Job Satisfaction Among Nurse in Aceh Timur District. Journal of Public Health and Development , 6(1),153162.

Schuler, R. S., \& Jackson, S. E. (1987). Organizational Strategy and Organizational Level as Detertminants of Human Resources Practices. Human Resources Planning, 10(3),125-141.

Shanock, L. R., \& Eisenberger, R. (2006). When Supervisors Feel Supported: Relationships With Subordinates' Perceived Supervisor Support, Perceived Organizational Support,and Performance. Journal of Applied Psychology, 91(3),689-695. doi:10.1037/0021-9010.91.3.689

Steers, R. M. (1977). Antecedents and outcomes of organizational commitment.

Administrative Science Quarterly, 22(1),46-56. doi:org/10.2307/2391745

Suliman, A., \& Al Kathairi, M. (2013). Organizational justice, Commitment and Performace in developing countries. Employee Relations, 35(1),98-115. doi:10.1108/01425451311279438

Sulu, S., Ceylan, A., \& Kaynak, R. (2010). Work alienation as a mediator of the relationship between organizational injustice and organizational commitment: implications of Healcare Professionals. International Journal of Business and Managment, 5(8),27-38.

Tepper, B. J., \& Taylor, E. C. (2003). Relationship among Supervisors' and Suordinates' Procedural Justice Perceptions and Organizational Citizenship Behaviors. Academy of Managment Journals, 46(1),97-105. doi:10.2307/30040679

Tett, R. T., \& Meyer, J. P. (1993). Job satisfaction, organisational commitment, turnover intention and turnover: Path analyses based on meta-analytic findings. Personnel Psychology, 46(2),259-293. doi:10.1111/j.17446570.1993.tb00874.x

Thurston, J. P., \& McNall, ,. L. (1986). Justice perceptions of performance appraisal practices. Journal of Managerial Psychology, 25(3), 201-228. doi:10.1108/02683941011023712 
Valentine, S., Godkin, L., Fleischman, G. M., \& Kidwell, R. (2010). Corporate Ethical Values, Group Creativity, Job Satisfaction and Turnover Intention: The Impact of Work Context on Work Response. Journal of Business Ethics, 98(3),353-372. doi:10.1007/s10551-010-0554-6

Wasti, S. A. (2003). Organizational commitment, turnover intentions and the influence of cultural values. Journal of Occupational and Organizational Psychology, 76(3),303-321. doi:10.1348/096317903769647193

Zahra, S., Irum, A., Mir, S., \& Chishti, A. (2013). Job Satisfaction and Faculty Turnover Intentions: A Case of Pakistani Universities. Journal of Business and Management, 9(2),83-89. doi:10.9790/487X-0928389

\section{Appendix}

Table 1: Response Characteristics

\begin{tabular}{l|l|l|l}
\hline $\begin{array}{l}\text { Questionnaire } \\
\text { Distributed }\end{array}$ & $\begin{array}{l}\text { Questionnaires } \\
\text { Retumed }\end{array}$ & Response Rate & $\begin{array}{l}\text { Questionnaires } \\
\text { used for analysis }\end{array}$ \\
\hline 200 & 190 & 190 \\
\hline
\end{tabular}

Table 2: Demographic characteristics

\begin{tabular}{l|l|l|l}
\hline Variables & Descriptions & $\mathrm{N}$ & Percent \\
\hline \multirow{2}{*}{ Gender } & Male & 110 & 57.89 \\
\cline { 2 - 4 } & Female & 80 & 42.11 \\
\hline \multirow{2}{*}{ Age } & 20 to 30 & 123 & 64.73 \\
\cline { 2 - 4 } & 31 to 40 & 34 & 17.89 \\
\cline { 2 - 4 } & 41 and above & 33 & 17.38 \\
\hline \multirow{2}{*}{ Nature of Job } & Academic & 77 & 40.53 \\
\cline { 2 - 4 } & Administrative & 113 & 59.47 \\
\hline
\end{tabular}


Table 3: Reliability test

\begin{tabular}{lllllll}
\hline & M & SD 1 & 2 & 3 & 4 & 5 \\
\hline 1 & Tumover Intention & 3.2 & $.86-$ & & & \\
\hline 2 & Job Satisfaction & 3.2 & $.84-.564^{* *}$ & & \\
\hline 3 & Affective Commitment & 2.4 & $.79-.357^{* *} .706^{* *}$ & \\
\hline 4 & Perceived Org. Support & 4.4 & $.70-.011^{* *} .207^{* *} .571^{*}$ & \\
\hline 5 & Distributive Justice & 3.3 & $.56-.045^{* *} .378^{* *} .577^{* *} .446^{*}-$ \\
\hline
\end{tabular}

Table 4: Correlation Analysis

\begin{tabular}{lll}
\hline Constructs & Items & Cronbach's Alpha \\
\hline Tumover Intention & 3 & 0.74 \\
Job Satisfaction & 8 & 0.81 \\
Perceived organizational Support & 8 & 0.79 \\
Affective Commitment & 5 & 0.72 \\
Distributive Justice & 5 & 0.77 \\
\hline
\end{tabular}

Table 5: Regression Analysis

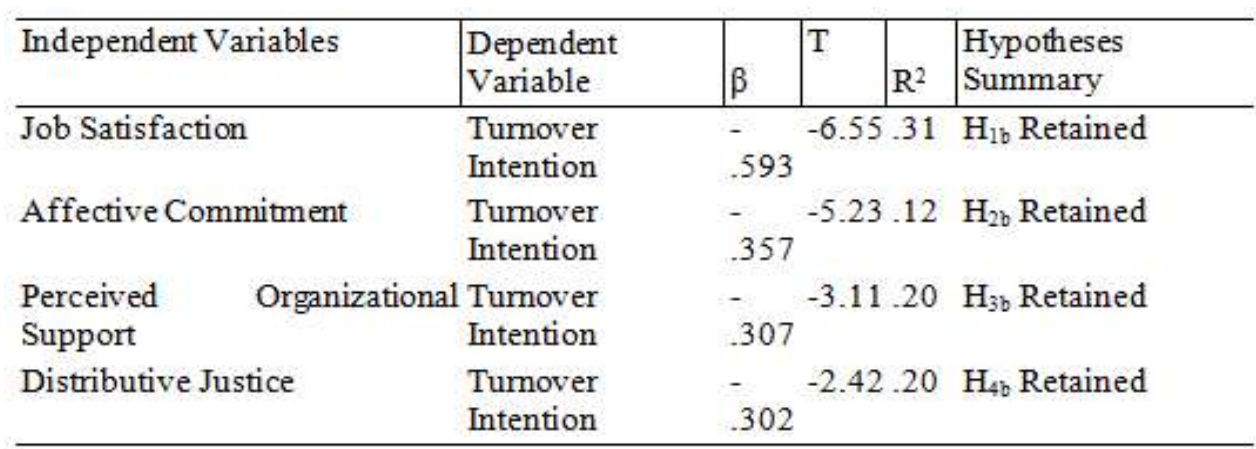

